\title{
Isabelle Constant, Le rêve dans le roman africain et antillais
}

\section{Stéphanie Celot}

\section{(2) OpenEdition}

10 Journals

\section{Édition électronique}

URL : http://journals.openedition.org/studifrancesi/8396

DOI : 10.4000/studifrancesi.8396

ISSN : 2421-5856

Éditeur

Rosenberg \& Sellier

\section{Édition imprimée}

Date de publication : 1 mai 2009

Pagination : 217-218

ISSN : 0039-2944

\section{Référence électronique}

Stéphanie Celot, «Isabelle Constant, Le rêve dans le roman africain et antillais », Studi Francesi [En ligne], 157 (LIII | I) | 2009, mis en ligne le 30 novembre 2015, consulté le 11 janvier 2021. URL : http:// journals.openedition.org/studifrancesi/8396; DOI : https://doi.org/10.4000/studifrancesi.8396

Ce document a été généré automatiquement le 11 janvier 2021.

\section{(c) (i) (9)}

Studi Francesi è distribuita con Licenza Creative Commons Attribuzione - Non commerciale - Non opere derivate 4.0 Internazionale. 


\title{
Isabelle Constant, Le rêve dans le roman africain et antillais
}

\author{
Stéphanie Celot
}

\section{RÉFÉRENCE}

ISABELLE CONSTANT, Le rêve dans le roman africain et antillais, Paris, Karthala, 2008, pp. 246.

1 Les ouvrages critiques qui s'intéressent à la fonction du rêve en littérature étant très nombreux, Isabelle Constant s'efforce, dès l'introduction, de s'en démarquer: «L'ambition de cet essai est de parvenir à proposer une théorie du rôle du rêve dans le roman, à partir d'un choix d'exemples et non d'appliquer des théories occidentales du rêve à ces exemples pour les analyser. Je cherche au contraire à m'éloigner de l'analyse psychologique. [...] Cet essai s'attache plutôt à la compréhension des moyens mis en œuvre pour écrire le rêve» (pp. 9-11). L'ouvrage est divisé en trois parties. La première, qui a pour titre «Approche du rêve», s'occupe des problèmes généraux concernant l'objet de la recherche: typologies, circonstances, poétique, rôle de l'oralité, tandis que la deuxième partie est consacrée à une «étude de cas»: ceux d'Amadou Hampaté Bâ, de René Depestre et de Simone Schwarz-Bart. La troisième partie, «Enquête et interview», contient les résultats d'une enquête menée en Afrique de l'Ouest et aux Antilles pour essayer d'établir un rapport entre les rêves réels d'un peuple et les rêves romanesques de ses écrivains. Cette troisième partie se conclut par une interview à Simone SchwarzBart sur l'utilisations des songes dans ses romans. Une bonne étude sur les implications littéraires de la présence des rêves dans l'œuvre romanesque. 